\title{
PERLINDUNGAN HUKUM TERHADAP PETERNAK SAPI PERAH DIKAITKAN DENGAN KEBERADAAN ASOSIASI PETERNAK SAPI PERAH DALAM UPAYA MENINGKATKAN KESEJAHTERAAN PETERNAK
}

\author{
Betharia Hasibuan \\ Fakultas Hukum Universitas Katholik Parahyangan \\ E-mail: bethariahasibuan@yahoo.com
}

\begin{abstract}
Dinamical Indonesia law often doing interaction with local wisdom which rise some kind of law regulation, that show connection between them. One of the dinamical situation is the farming regulation. The farming regulation not only regulate for farming protection, quality of livestock resources, halal and food safety,technology development, rise on nation income but also enlarge working chances for social welfare.Goverment role become important to give direction and to provide suitable farming regulation and goverment role on dairy farmers approach. Library reseacrch is the metodology approach which use in these research. Logical way for shading dairy farmers is by association with the goverment regulation as principal to conduct for protection themselves and for the social welfare
\end{abstract}

Keywords: law protection; association; dairy farmers.

\begin{abstract}
Abstrak
Hukum Indonesia yang dinamis sering kali berinteraksi dengan kearifan lokal sehingga memuncul berbagai macam aturan hukum yang terkait dengan hal tersebut. Salah satu bentuk kedinamisan tersebut berkaitan dengan munculnya pengaturan tentang peternakan. Pengaturan bidang pertenakan yang muncul tidak hanya untuk melindungi dan meningkatkan kualitas sumber daya hewan; menyediakan pangan yang aman, sehat, utuh, dan halal; meningkatkan derajat kesehatan masyarakat, hewan, dan lingkungan; menyediakan jasa dan bahan baku industri; mengembangkan ilmu pengetahuan dan teknologi; meningkatkan pendapatan dan devisa negara; melainkan pula memperluas kesempatan berusaha dan kesempatan kerja; serta meningkatkan kesejahteraan rakyat. Penting untuk dipahami peran pemerintah menjadi penting untuk memberikan arahan melalui regulasi yang dibentuk dan diterbitkan dengan menitikbertkan kepada dua hal ini yaitu: Ketersediaan peraturan perundang-undangan tentang Asosiasi Peternak Sapi Perah yang memadai dan peran Pemerintah terkait dengan peningkatan kesejateraan peternak melalui pendekatan asosiasi. Penelitian ini menggunakan metode studi kepustakaan Perlindungan terhadap hak-hak yang dimiliki oleh peternak sapi perah tidak boleh diabaikan, Asosiasi atau perkumpulan yang menaungi para peternak sapi perah merupakan cara logis untuk dapat menjalankan kebijakan-kebijakan yang terkait dengan kewajiban dan hak-hak yang dimiliki oleh peternak sapi perah. Tugas asosiasi ini menjadi penyeimbang sebagai bagian dari Negara yang memiliki tugas dan fungsi sebagai sebuah organisasi dengan mengedepankan perlindungan melalui regulasi dalam bentuk peraturan perundang-undangan.
\end{abstract}

Kata Kunci: Perlindungan Hukum, Asosiasi, Peternak Sapi Perah. 


\section{A. PENDAHULUAN}

Salah satu hal yang menarik dalam perjalanan hukum Indonesia adalah muncul pengaturan tentang peternakan. Pengaturan bidang pertenakan yang muncul tidak hanya untuk melindungi dan meningkatkan kualitas sumber daya hewan; menyediakan pangan yang aman, sehat, utuh, dan halal; meningkatkan derajat kesehatan masyarakat, hewan, dan lingkungan; menyediakan jasa dan bahan baku industri; mengembangkan ilmu pengetahuan dan teknologi; meningkatkan pendapatan dan devisa negara;, melainkan pula memperluas kesempatan berusaha dan kesempatan kerja; serta meningkatkan kesejahteraan rakyat. ${ }^{1}$

Pengaturan tentang peternakan memiliki perbedaaan dengan bidang pertanian, Sesuai amanat dalam UndangUndang No. 17 tahun 2007 tentang Rencana Pembangunan Jangka Panjang Nasional (RPJPN) 2005-2025, saat ini memasuki periode Rencana Pembangunan Jangka Menengah Nasional (RPJMN) tahap ke-2 (2010-2014), setelah periode RPJMN tahap ke-1 (2005-2009) berakhir. Pada RPJMN tahap ke-2 (2010-2014), melalui Renstra Kementerian Pertanian 2010-2014 pembangunan pertanian tetap memegang peran yang strategis dalam perekonomian nasional. Peran strategis pertanian tersebut digambarkan melalui kontribusi yang nyata melalui pembentukan kapital, penyediaan bahan pangan, bahan baku industri, pakan dan bio-energi, penyerap tenaga kerja, sumber devisa negara, dan sumber pendapatan, serta pelestarian lingkungan melalui praktek usaha tani yang ramah lingkungan. ${ }^{2}$

Keadaan ini berlanjut dengan begitu rincinya pertanian dibahas secara jelas dalam RPJMN (Rencana Pembangunan Jangka Menengah) Tahun 2015-2019 yang berasosiasi dengan prioritas pembangunan kedaulatan pangan dengan peningkatan produksi padi, produksi kedelai, produksi jagung, dan terbangunnya dan meningkatnya layanan jaringan irigasi 1 juta hektar; terlaksananya rehabilitasi 3 juta ha jaringan irigasi untuk mengembalikan layanan irigasi, beroperasinya dan terpeliharanya jaringan irigasi 7,3 juta Ha.

Realita lain tentang pentingnya bidang pertanian dibandingkan bidang peternakan dalam kehidupan bangsa Indonesia adalah munculnya gagasangagasan untuk menjalankan pembaruan

1 Penjelasan Paragraf 3 Undang-Undang Nomor 18 Tahun 2009 tentang Peternakan Dan Kesehatan Hewan.

2 Secara makro pembangunan pertanian dituangkan pada visi pembangunan pertanian 2025 yang pertama kali dicanangkan pada era pemerintahan Presiden Susilo Bambang Yudhoyono dengan Kabinet Indonesia Bersatu jilid I. Pada seminar dan lokakarya nasional 12 Maret 2005 tentang "Arah kebijakan pembangunan pertanian nasional pada kabinet Indonesia bersatu", Menteri Pertanian kala itu dijabat oleh Anton Apriyantono, menyampaikan pidato yang menyatakan bahwa, pembangunan pertanian masih dihadapkan kepada sejumlah kendala dan masalah yang harus dipecahkan, antara lain : (1) Keterbatasan dan penurunan kapasitas sumberdaya pertanian, (2) Sistem alih teknologi yang masih lemah dan kurang tepat sasaran, (3) Keterbatasan akses terhadap layanan usaha, terutama permodalan, (4) Rantai tata niaga yang panjang dan sistem pemasaran yang belum adil, (5) Kualitas, mentalis, keterampilan sumberdaya petani rendah, (6) Kelembagaan dan posisi tawar petani rendah, (7) Lemahnya koordinasi antar lembaga terkait dan birokrasi, dan (8) Kebijak n makro ekonomi yang belum berpihak kepada petani. 
agraria yang menguat kembali pada awal tahun 90-an, ketika sekelompok ornop, organisasi tani dan sejumlah scholar-activist membentuk Konsorsium Pembaruan Agraria (KPA). Seperangkat gagasan dan petunjuk untuk menjalankan pembaruan agraria dipertemukan secara konsepsual dengan gagasan penegakan prinsip-prinsip baru pengelolaan sumber daya yang berkeadilan. ${ }^{3}$

Tata kelola peternakan yang melindungi peternak dan peternakan merupakan gambaran terhadap perlindungan kekayaan keanekaragaman hayati dan sumber daya alam yang melimpah secara terpadu dan terintegrasi berdasarkan wawasan Nusantara. Pengelolaan tersebut harus dapat memberikan kemanfaatan ekonomi, sosial, dan budaya dilaksanakan berdasarkan prinsip kehati-hatian, taat asas dan konsekuen dari pusat sampai daerah. Hal ini menuntut kalangan hukum untuk melakukan pendekatan interdisipliner dan lintas sektoral. Beberapa sektor yang terkait dapat disebutkan diantaranya sektor kependudukan, kesehatan, transmigrasi, pemukiman dan perumahan, pertambangan, perindustrian, pertanian, (peternakan) kehutanan, kelautan, perdagangan, perikanan, pengairan, penataan ruang, dan sektor-sektor lain. ${ }^{4}$

Tata kelola yang baik terjabarkan dalam regulasi tentang pelaksanaan tugas, fungsi serta kewenangan dan penjabaran peran Kementerian Pertanian dalam mencapai sasaran strategis, sebagaimana diatur dalam undang-undang terkait dan turunannya. Regulasi tersebut dibutuhkan dalam menyelesaikan permasalahan yang dihadapi dalam pembangunan pertanian dan peternakan baik di tingkat pusat hingga di tingkat daerah. Regulasi yang terkait dengan sektor pertanian, baik dalam bentuk undang-undang, peraturan presiden, maupun dalam bentuk peraturan Menteri Pertanian serta produk peraturan operasional lainnya di level pusat, propinsi dan kabupaten/kota. Kerangka regulasi yang telah ada atau yang dibutuhkan, dikelompokkan mulai dari kebutuhan regulasi terkait input pertanian seperti pemanfaatan sumberdayagenetik, jaminan ketersediaan pupuk dan benih, dukungan infrastruktur, serta regulasi yang terkait lahan dan alsintan. Sedangkan regulasi yang terkait dengan kegiatan budidaya tentunya yang terkait dengan jaminan usaha-tani tanaman pangan, hortikultura, peternakan, perkebunan, perlindungan dan pemberdayaan petani/peternak. ${ }^{5}$

Keberhasilan penyelenggaraan peternakan dan kesehatan hewan diatur juga mengenai pemberdayaan peternak, perusahaan peternakan dan pelayanan kesehatan hewan, pengembangan sumber daya manusia, penelitian dan pengembangan, serta sumber daya permodalan. Disadari bahwa pengaturan dalam Undang-Undang ini belum

3 Dainto Bachriadi, Refleksi Satu Dasarwa Reformasi dalam Perspektif Reforma Agraria, Jurnal Analisis Sosial Vpl. 15 No. 1 Agustus 2010, hlm. 9.

$4 \quad$ Sutrisno, Politik Hukum Perlindungan dan Pengelolaan Lingkungan Hidup, Jurnal Hukum Universitas Islam Indonesia, No. 3 Vol. 18 Juli 2011, hlm. 446 dan 447.

5 Lampiran Peraturan Menteri Pertanian Nomor 19/Permentan/HK.140/4/2015 Tentang Rencana Strategis Kementerian Pertanian Tahun 2015-2019, hlm. 174-175. 
sepenuhnya mencakup aspek kehewanan dalam arti luas. Jangkauan pengaturan baru pada hewan budi daya, yaitu ternak, hewan kesayangan, dan hewan laboratorium. Untuk itulah diperlukan suatu undang-undang tersendiri yang mengatur mengenai aspek kehewanan secara komprehensif termasuk pengaturan praktik kedokteran hewan (veteriner). ${ }^{6}$ Bagi Negara-negara Agraris umumnya pembangunan peternakan dianggap merupakan tahap strategis dalam rangka menuju proses industrialisasi, oleh karena:

1. Meningkatnya produktivitas subsektor peternakan akan menciptakan pasar yang makin luas bagi produk-produk industri dan memberi dukungan makin kuat terutama bagi industriindustri yang menggunakan hasil peternakan sebagai bahan bakunya.

2. Tersedianya barang-barang kebutuhan pokok penduduk dalam jumlah yang cukup dan dengan harga yang relatif murah, memberi peluang bagi sektor industri untuk menekan biaya produksi terutama melalui komponen upah tenaga kerja, sehingga dapat mendorong beroperasinya sektor industri yang memiliki daya saing cukup kuat.

3. Pembangunan subsektor peternakan yang berhasil meningkatkan pendapatan penduduk desa, dapat menciptakan rangsangan bagi perluasan akumulasi kapital yang bila diperlukan dapat digunakan untuk tujuan produktif.?

Khusus bagi pemberdayaan peternak upaya meningkatkan produkftivitas pertanian (peternakan), petani (peternak) miskin, usaha perikanan tangkap maupun budi daya, dan usaha skala mikro lainnya yang menunjang rantai produksi usaha kecil yang menjadi potensi di wilayah. Ketersediaan sarana dan prasarana perekonomian di daerah pedesaan, akses pada kredit jasa keuangan dan sumber permodalan lainnya bagi pelaku ekonomi di pedesaan, serta pemanfaatan riset dan teknologi pertanian, diseminasi dan penyediaan informasi teknologi pertanian juga menjadi faktor penting dalam mendorong ekonomi perdesaan yang membawa kepada kesejahteraan. ${ }^{8}$

Patut dipahami bahwa peternakan layaknya pertanian yang lahir bersamaan denganlahirnyamasyarakatIndonesiayang muncul bermula dari pedesaan, peternakan mempunyai peran penting terhadap perbaikan kehidupan masyarakat yang menggantungkan hidupnya dalam bidang tersebut. Peternakan pula merupakan kekayaan keanekaragaman hayati yang sangat besar (mega biodiversity) berupa sumber daya hewan dan tumbuhan, sebagai anugerah sekaligus amanah Tuhan Yang Maha Esa. Kekayaan tersebut perlu dimanfaatkan dan dilestarikan dalam mewujudkan kesejahteraan seluruh rakyat Indonesia, sebagaimana tercantum dalam

6 Penjelasan Paragraf 8 Undang-Undang Nomor 18 Tahun 2009 tentang Peternakan Dan Kesehatan Hewan.

7 Lilis Nurlina, Op.Cit., hlm. 5.

8 Lampitan Peraturan Presiden No. 2 Tahun 2015 tentang Rencana Pembangunan Jangka Menengah Nasional 2015-2019 Buku I Agenda Pembangunan Nasional, Kementerian Perencanaan Pembangunan Nasional/Badan Perencanaan Pembangunan Nasional, 2014, hlm. 2-12. 
Pembukaan Undang-Undang Dasar Negara Republik Indonesia Tahun $1945 .{ }^{9}$

Tiap-tiap pemangku kepentingan (stakeholders) memiliki perannya masingmasing. Pertama, Pemerintah memiliki peran untuk menentukan arah melalui kebijakan yang dibuat dalam rangka meningkatkan produktifitas peternak sapi perah dalam melakukan kegiatan peternakannya, baik dalam bentuk peraturan maupun pengembangan teknologi. Kedua, Peternak sapi perah memiliki peran melaksanakan kebijakakebijakan yang telah ditentukan oleh Pemerintah. Ketiga, Industri Pengolahan Susu memiliki peran mendayagunakan hasil produksi susu dari peternak sapi perah kepada masyarakat.

Asosiasi sebagai wadah bagi peternak sapi perah menjadi bagian penting untuk melindungi berbagai kepentingan yang terkait dengan kelangsunagn peternakan dan peternakan sapi perah itu sendiri. Layaknya koperasi yang menjadi suatu wadah untuk untuk menjalankan suatu usaha, dengan maksud memenuhi aspirasi dan kebutuhan bersama di bidang ekonomi, sosial, dan budaya sesuai dengan nilai dan prinsip Koperasi. ${ }^{10}$ Perlindungan yang diberikan oleh Koperasi berdasrkan kepada kedudukan dan kewenangan yang dimiliki sebagai badan hukum yang memungkinkan untuk melakukan tindakan layaknya subjek hukum orang, dalam pengertian melakukan tindakan hukum baik secara litigasi maupun non litigasi untuk melindungi tujuan dari koperasi tersebut, termasuk di dalamnya anggota-anggota dari koperasi itu serndiri.

Pentingnya menempatkan asosiasi termasuk didalamnya asosiasi peternak sapi perah sebagai sebuah wadah untuk melindungi para petani sapi perah, dari keadaan-keadaan yang tidak menguntungkan, baik itu karena aturan dan kebijakan Pemerintah, maupun berasal dari sektor swasta yang diwakili oleh Industri Pengelolahan Susu. Contoh yang dapat menggambarkan pentingnya pembentukan Asosiasi terlihat dari harga susu yang rendah di tingkat peternak sapi perah disebabkan menyusutnya jumlah sapi perah di Indonesia. Hal ini secara langsung berimbas pada jumlah produksi susu sapi, dengan diikuti oleh tidak ada revisi harga susu dan harga pakan. ${ }^{11}$

Pendayagunaan asosiasi sebagai sebuah wadah pula merupakan paradigma baru pembangunan peternakan semakin nyata berorientasi pada manusia dimana pembangunan peternakan meletakkan peternak sebagai subyek, bukan sematamata sebagai obyek dalam mencapai tujuan nasional. Berdasarkan paradigma tersebut maka visi pembangunan peternakan adalah terwujudnya masyarakat yang sehat, produktif dan kreatif melalui pembangunan peternakan tangguh berbasis sumberdaya lokal dengan misi penyediaan pangan asal ternak (daging,

9 Penjelasan Paragraf 1 Undang-Undang Nomor 18 Tahun 2009 tentang Peternakan Dan Kesehatan Hewan.

10 Pasal 1 Undang-Undang No. 17 Tahun 2012 tentang Perkoperasian, Catatan undang-undang ini telah dibatlkan oleh Mahkamah Konsitusi pada Tahun 2014.

11 http://www.cnnindonesia.com/ekonomi/20160422185106-92-125934/produksi-susu-sapiindonesia-tersumbat-rendahnya-harga/, Diakses terakhir pada 1 Agustus 2016 pukul 11.30 Waktu Indonesia Barat (WIB). 
telur, susu), pemberdayaan sumberdaya manusia peternak, penciptaan peluang ekonomi dan lapangan kerja serta pelestarian/pemanfaatan sumberdaya alam. ${ }^{12}$

Peran-peran ini muncul tidak secara tiba-tiba melainkan disertai dengan landasan yang menberikan batasbatas kewenangan yang dimiliki oleh ketiga pemangku kepentingan tersebut. Landasan tersebut dikenal dengan hukum yang meemiliki berbagai fungsi tergantung subjek dan objek hukum. Khusus dalam ranah peternakan dengan orientasi pembangunan dan pengembangan tata kelola peternakan yang baik, Hukum difungsikan sebagai pelayanan kebutuhan masyarakat, maka hukum harus selalu diperbaharui agar aktual atau sesuai dengan keadaan serta kebutuhan masyarakat yang dilayani dan dalam pembaharuan hukum yang terus menerus dengan menempatkan keseimbangan dalam seluruh aspek penyelenggaraan negara antara lain: Pertama, keseimbangan lahir dan batin dalam makna kemajuan ekonomi. Kedua, keseimbangan antara internasionalitas (kosmopoliteisme) dan kebangsaan (nasionalisme). Ketiga, keseimbangan kepentingan negara dan rakyat. Keempat, keseimbangan antara demokrasi politik dan demokrasi ekonomi. Kelima, keseimbangan antara individu, masyarakat, bangsa dan negara. ${ }^{13}$

Keadaan ini ditujukan untuk merefleksikan makna dari perlindungan hukum yang memiliki hakikat dalam penegakan ide-ide serta konsepkonsep yang abstrak. Dengan kata lain, perlindungan hukum merupakan suatu usaha untuk mewujudkan ideide keseimbangan dalam kenyataan. Proses mewujudkan ide-ide inilah yang merupakan hakikat dari penegakan hukum, akan tetapi perlindungan hukum tidak hanya diartikan sebagai penegakan hukum yang bertindak untuk memaksa orang atau pihak yang tidak mentaati ketentuan yang berlaku untuk menaati peraturan tersebut. Perlindungan hukum juga dapat diartikan sebagai tindakan untuk mempengaruhi orang atau berbagai pihak yang terkait dengan pelaksanaan ketentuan hukum, sehingga hukum tersebut dapat berlaku sebagaimana mestinya. ${ }^{14}$

Perlindungan hukum ditujukan pula demi terwujud dan terlaksananya kesejahteraan dengan peningkatan taraf hidup, terutama bila terkait kepada peternak agar terlepas dari kemiskinan yang cenderung mengikat golongan lemah dengan kondisi dimana seseorang atau sekelompok orang laki dan perempuan, yang tidak mampu memenuhi hakhak dasarnya untuk mempertahankan dan mengembangkan kehidupan yang bermartabat. Hak-hak dasar manusia tersebut meliputi: terpenuhinya kebutuhan pangan, sandang, kesehatan, pendidikan, pekerjaran, penunahan,

12 Rizaldy Muhammad Milad, Sa'adatul Munawaroh, dan Yuni Ningtiyas, Perkembangan Mata Pencaharian Peternakan, Artikel Ilmiah, Universitas Negeri Malang, 2014, hlm. 1 dan 3.

13 Dani Pinasang, Falsafah Pancasila Sebagai Norma Dasar (Grundnorm) Dalam Rangka Pengembanan Sistem Hukum Nasional, Dinamika Hukum Vol.XX/No.3/April-Juni/2012, hlm. 7-8

14 Deden Sumantry, Reformasi Perpajakan Sebagai Perlindungan Hukum Yang Seimbang Antara Wajib Pajak Dengan Fiskus Sebagai Pelaksanaan Terhadap Undang-Undang Perpajakan, Jurnal Legislasi Indonesia, Vol. 8 No. 1 - April 2011, hlm. 22. 
air bersih, pertanahan, sumber daya alam dan lingkungan hidup, rasa aman dari perlakuan atau arncaman tindak kekerasan dan hak untuk berpartisipasi dalam kehidupan sosial politik. ${ }^{15}$

Asosiasi menjadi penting untuk mendorong kedua hal tersebut melalui pengembangan wawasan dan paradigma baru di bidang peternakan agar investasi, inovasi, dan pemberdayaan di bidang peternakan terus berlanjut dan meningkat sehingga meningkatkan daya saing bangsa dan kesetaraan dengan bangsa lain yang lebih maju. ${ }^{16}$ Peran ini di terkait dengan proses penyelenggaraan peternakan meliputi tanah atau lahan, air, sumber daya genetik, benih, bibit, bakalan, pakan, alat dan mesin peternakan, budi daya, panen dan pascapanen, pemasaran, dan pengolahan hasil peternakan. Bagi hasil ini haruspulaselarasdengan penyelenggaraan kesehatan hewan meliputi penyakithewan, obat hewan, alat dan mesin, kesehatan masyarakat veteriner, kesejahteraan hewan, dan otoritas veteriner. Dalam otoritas veteriner diatur hal mengenai penguatan fungsi, pelayanan kesehatan hewan, tenaga kesehatan hewan, medik reproduksi, medik konservasi, forensik veteriner, dan kedokteran perbandingan. ${ }^{17}$

Idealitas ini menunjukkan bahwa setiap manusia memegang peran penting untuk melaksanakan maksud dari perlindungan hukum untuk mencapai dan memperoleh kesejahteraan. Kesejahteraan oleh sebagian masyarakat selalu dikaitkan dengan konsep kualitas hidup. Konsep kualitas hidup merupakan gambaran tentang keadaan kehidupan yang baik. Kualitas hidup sebagai sebuah persepsi individu terhadap kehidupannya di masyarakat dalam konteks budaya dan sistem nilai yang ada yang terkait dengan tujuan, harapan, standar, dan juga perhatian terhadap kehidupan. Konsep ini memberikan makna yang lebih luas karena dipengaruhi oleh kondisi fisik individu, psikologis, tingkat kemandirian, dan hubungan sosial individu dengan lingkungannya. ${ }^{18}$

Penting untuk dipahami peran pemerintah menjadi penting untuk memberikan arahan melalui regulasi yang dibentuk dan diterbitkan dengan menitikbertkan kepada dua hal ini yaitu: Ketersediaan peraturan perundangundangan tentang Asosiasi Peternak Sapi Perah yang memadai dan peran Pemerintah terkait dengan peningkatan kesejateraan peternak melalui pendekatan asosiasi. Penelitian ini menggunakan metode studi kepustakaan (library research) dengan menempatkan penelitian hukum sebagai suatu kegiatan ilmiah yang didasarkan pada metode, sistematika dan pemikiran tertentuyangbertujuan untukmempelajari satu atau beberapa gejala hukum tertentu, dengan jalan menganalisanya kemudian

15 Erwan Agus Purwanto, Mengkaji Potensi Usaha Kecil dan Menengah (UKM) untuk Pembuatan Kebiiakan Anti Kemiskinan di Indonesia, Jurnal Ilmu Sosial dan Ilmu Politik, Volume 10, Nomor 3, Maret 2007, hlm. 300.

16 Penjelasan Paragraf 2 Undang-Undang Nomor 18 Tahun 2009 tentang Peternakan Dan Kesehatan Hewan.

17 Penjelasan Paragraf 7 Undang-Undang Nomor 18 Tahun 2009 tentang Peternakan Dan Kesehatan Hewan.

18 Adi Fahrudin, Pengantar Kesejahteraan Sosial, Refika Aditama, Bandung, 2012, hlm. 8. 
mengusahakan suatu pemecahan atas permasalahan-permasalahan yang timbul di dalam gejala yang bersangkutan." ${ }^{19}$

\section{B. PEMBAHASAN}

\section{Perlindungan Hukum}

Perlindungan hukum adalah perlindungan akan harkat dan martabat, serta pengakuan terhadap hak-hak asasi manusia yang dimiliki oleh subyek hukum berdasarkan ketentuan hukum dari kesewenangan atau sebagai kumpulan peraturan atau kaidah yang akan dapat melindungi suatu hal dari hal lainnya. Berkaitan dengan konsumen, berarti hukum memberikan perlindungan terhadap hak-hak pelanggan dari sesuatu yang mengakibatkan tidak terpenuhinya hak-hak tersebut. ${ }^{20}$

Perlindungan hukum memiliki ruang lingkup yang luas, keluasaannya dapat dipersempit sesuai dengan subjek dan objek hukum yang akan dilindungi. Kedua kata tersebut dapat terdapat dalam ranah hukum pidana, perdata, internasional, tata negara bahkan hukum administrasi negara. Perlindungan hukum dalam ranah pidana ditujukan terhadap individu dari tindakan-tindakan yang merugikannya dengan adanya intervensi negara dalam penegakan hukumnya. Hukum perdata memaknai perlindungan hukum ditujukan kepada para pihak yang melakukan hubungan hukum secara keperdataan atau didasarkan kepada perikatan yang muncul baik melalui perjanjian maupun undangundang.

Perlindungan hukum internasional (publik) ditujukan terhadap individu/ masyarakat akibat tindakan-tindakan individu yang secara nyata melakukan kejahatan kemanusian seperti: pembunuhan, pemusnahan, perbudakan. ${ }^{21}$ Hukum tata negara dan administrasi negara dikaitkan dengan perlindungan terhadap individu dan masyarakat dari kesewenangan-wenangan kekuasaan negara dalam menjalankan tugas dan fungsinya. Perbedaan yang mendasar dari keduanya dalam tindakan yang dilakukan negara. Hukum tata negara berkaitan dengan tindakan organisasi negara terhadap masyrakat, sedangkan hukum administrasi negara berkenaan dengan tindakan pejabat negara terhadap individu tertentu bila bersifat beschiking (putusan).

Perlindungan hukum mereprsentasikan tiga unsur yang menekankan fungsi hukum yaitu kepastian hukum (rechtssicherheit), kemanfaatan (zweckmassigkeit), dan keadilan (gerechtigkeit). kepastian hukum merefleksikan penetapan suatu aturan baik tidak tertulis maupun tertulis apabila telah terjadi penyimpangan terhadap suatu peristiwa konkrit. Kemanfaatan ditujukan untuk manfaat dan kegunaan bagi masyarakat. Hukum identik dengan keadilan. Hukum bersifat umum, mengikat setiap orang, bersifat menyamaratakan. ${ }^{22}$ Perlindungan

19 Suharsimi Arikunto, Prosedur Penelitian Suatu Pendekatan Praktek, Rineka Cipta, Jakarta, 1997 ed. Revisi V. hlm. 43.

20 Philipus M. Hadjon, Perlindungan Hukum bagi Rakyat di Indonesia, Bina Ilmu, Surabaya, 1987, hlm. 25.

21 Lihat Pasal 9 Undang-Undang No. 26 tahun 2000 tentang Pengadilan Hak Asasi Manusia (HAM) di Indonesia.

22 Sudikno Mertokusumo, Bab-Bab Tentang Penemuan Hukum, Citra Adtya Bakti, Bandung, 1993, hlm. $1-2$. 
hukum bagi rakyat merupakan konsep universal, dalam arti dianut dan diterapkan oleh setiap negara yang mengedepankan diri sebagai negara hukum, namun seperti disebutkan Paulus Lotulung bahwa masing-masing negara mempunyai cara dan mekanisme Sendiri tentang bagaimana mewujudkan perlindungan hukum dan sampai seberapa jauh perlindungan hukum itu diberikan. Selanjutnya Paulus Lotulung menyatakan bahwa bidang-bidang perlindungan hukum, perlu pula dikemukakan mengenai macam-macam perbuatan pemerinfah yang memungkinkan Iahirnya kerugian bagi masyarakat dan / atau bagi seseorang atau badan hukum perdata. Secara umum ada tiga macam perbuatan pemerintah yaitu perbuatan pemerintah dalam bidang pembuatan peraturan perundangundangan (regeling), perbuatan pemerintah dalam penerbitan ketetapan (materiele daad). Dua bidang pertama terjadi dalam bidang publik, dan karena itu tunduk dan diatur berdasarkan hukum publik, sedangkan yang terakhir khusus dalam bidang perdata dan oleh karenanya tunduk dan diatur berdasarkan hukum perdata. ${ }^{23}$

Universalitas perlindungan hukum berupaya melindungi harkat dan martabat manusia dari pemerkosaan yang pada dasarnya serangan hak pada orang lain telah melanggar aturan norma hukum dan undang-undang. ${ }^{24}$ perlindungan ini menuntut Hukum berfungsi sebagai perlindungan kepentingan manusia. Agar manusia terlindungi, hukum harus dilaksanakan. Pelaksanaan hukum dapat berlangsung secara normal, damai, tetapi dapat terjadi juga karena pelanggaran hukum. Pelanggaran hukum terjadi ketika subjek hukum tertentu tidak menjalankan kewajiban yang seharusnya dijalankan, atau karena melanggar hak-hak subjek hukum lain. Subjek hukum yang dilanggar hak-haknya harus mendapatkan perlindungan hukum. ${ }^{25}$

Indonesia sebagai negara hukum telah dinormativisasi pada Pasal 1 ayat (3) Undang-Undang Dasar 1945 perubahan ke-4 yang menegaskan bahwa "Negara Indonesia adalah negara hukum (rechtsstaat)". Dengan penegasan itu, maka mekanisme kehidupan perorangan, masyarakat, dan negara diatur oleh hukum (tertulis maupun tidak tertulis). Artinya baik anggota masyarakat maupun pemerintah wajib mematuhi hukum tersebut. $^{26}$ Negara pada tingkatan ini dituntut tidak hanya bertugas memelihara ketertiban masyarakat, akan tetapi dituntut untuk turut serta aktif dalam semua aspek kehidupan dan penghidupan rakyat. Kewajiban ini merupakan amanat pendiri negara (the founding fathers) Indonesia, seperti dikemukakan pada

23 M. Syukri Akub, Baharuddin Baharu, Wawasan Due Proses Of Law Dalam Sistem Peradilan Pidana, Rangkang Education, Yogyakarta, 2012, hlm. 38.

24 Satjipto Rahardjo, Penyelenggaraan Keadilan dalam Masyarakat Yang Sedang Berubah, Jurnal Masalahmasalah Hukum, Nomor: 1-6 Tahun x/10, 1993), hlm. 70.

25 Mukhti Fadjar, Tipe Negara Hukum, Banyumedia, Malang, 2004, hlm. 28-29.

26 Baharudin Lopa, Permasalahan Pembinaan Dan Penegakan Hukum Di Indonesia, Bulan Bintang, Jakarta, 1987, hlm. 101. 
alinea ke-4 Pembukaan Undang-Undang Dasar 1945. ${ }^{27}$

Motivasi ini mengarahkan Indonesia memaknai negara hukum sebagai negara yang memiliki fungsi sebagai penengah jika terjadi perselisihan di antara warga negara. Fungsi ini menunjukkan negara sebagai pejaga malam atau Nachwachter Staat, untuk menjamin ketiadaan tindakan sewenang-wenang dari negara dalam menyelenggarakan pemerintahan. Stahl menngemukakan dua unsur tambahan yaitu: Pertama, setiap tindakan harus berdasarkan undang-undang yang dibuat terlebih dahulu. Negara dapat bertindak jika telah diatur melalui undang-undang mengenai tindakan tersebut. Kedua, peradilan administrasi untuk menyelesaikan perselisihan antara penguasa dan rakyat didasari oleh persyaratan-persyaratan tertentu, dan peradilan tidak diperbolehkan untuk memihak pihka yang bersengketa serta dilakukan oleh ahli hukum. ${ }^{28}$

Tanggungjawab yang dimiliki oleh negara merupakan titik tolak negara kesejahteraan itu tercapai didalamnya negara mengatur agar sumber-sumber kemakmuran tidak dikuasai oleh segelintir orang. Paham ini lebih dipelopori oleh aliran sosialisme yang menentang paham individualisme, liberalism, dan kapitalisme, yang memunculkan konsep welfare state berkembang di negara-negara Eropa, bahkan meluas hampir ke seluruh negara-negara di dunia. Tanggungjawab merupakan keikitsertaan negara secara aktif untuk kesejahteraan rakyatnya yang kemudian dikenal dengan nama verzorgingsstaat, atau disebutnya sociale rechtsstaat (negara hukum sosial). Dalam pengertian modern, pemerintah dituntut untuk mewujudkan kesejahteraan dan keadilan sosial bagi seluruh rakyatnya. ${ }^{29}$

\section{Asosiasi}

Asosiasi yaitu kelompok yang anggotanya mempunyai kesadaran jenis dan ada persamaan kepentingan pribadi maupun kepentingan bersama. Dalam asosiasi, para anggotanya melakukan hubungan sosial, kontak dan komunikasi, serta memiliki ikatan organisasi formal..$^{30}$ Ciri-ciri yang menjadi dasar suatu kelompok dapat dikatakan sebagai sebuah asosiasi adalah sebagai berikut: ${ }^{31}$

a. Terdapat dorongan atau motif yang sama antar individu satu dengan yang lain.

b. Terdapat akibat-akibat interaksi yang berlainan terhadap individu satu dengan yang lain berdasarkan rasa dan kecakapan yang berbeda-beda antara individu yang terlibat di dalamnya.

c. Adanya penegasan dan pembentukan struktur atau organisasi kelompok

\footnotetext{
$27 \quad$ Ni Gusti Ayu Hendrani Sukma Lestari, Eksistensi Klausul Pengaman Dalam Keputusan Gubernur Bali Yang Berkarakter Keputusan Tata Usaha Negara, Tesis Program Magister Program Studi Ilmu Hukum Program Pascasarjana Universitas Udayana, Denpasar, 2010, hlm. 13.

28 Juniarso Ridwan, Achmad Sodik Sudrajat, Hukum Administrasi Negara Dan Kebijakan Pelayan Publik, Nuansa Cendekia, Bandung, 2014, hlm. 59.

29 Rudy Hendra Pakpahan dan Eka N. A. M. Sihombing, Tanggung Jawab Negara dalam Pelaksanaan Jaminan Sosial, Jurnal Legislasi Indonesia, Vol. 9 No. 2 - Juli 2012, hlm. 168.

30 Anonim.

31 Anonim.
} 
yang jelas dan terdiri dari perananperanan dan kedudukan masingmasing.

d. Adanya peneguhan norma pedoman tingkah laku anggota kelompok yang mengatur interaksi dalam kegiatan anggota kelompok untuk mencapai tujuan yang ada.

e. Berlangsungnya suatu kepentingan.

f. Adanya pergerakan yang dinamik.

Asosiasi dituntut untuk melakukan penguatan dengan mengedepankan peran serta anggota-anggota yang menjadi kekuatan dalam keberkembangan asosiasi tersebut. Tuntutan terhadap asosiasi sebagai pengemban amanat dalam memperjuangkan kepentingankepentingan anggota yang tergabung dalam asosiasi tersebut tidak hanya terkait dengan kepentingan perekonomian, melainkan pula dengan perannya sebagai sebuah perkumpulan. Kedudukan ini penting untuk menentukan keberlangsungan program-program operasional dalam peternak sapi perah demi merangsang kegiatan ekonomi produktif di tingkat rakyat sekaligus memupuk jiwa kewirausahaan merupakan tujuan utama dari ekonomi kerakyatan., sebagaimana diketahui sebuah organisasi dengan kedudukan badan hukum memiliki perbedaan dengan yang tidak berbadan hukum. ${ }^{32}$

Kedudukan asosiasi sebagi sebuah organisasi dapat pula menjadi bantuan terhadap peran pemerintah menjadi penting untuk melakukan perubahanperubahan struktural dan normatif dalam pembangunan yang berpusat pada rakyat: Pertama, kebijakan pemerintah harus dipusatkan pada pemikiran dan tindakan penciptaan keadaan-keadaan yang mendorong dan mendukung usahausaha rakyat untuk memenuhi kebutuhankebutuhan mereka sendiri, dan untuk memecahkan masalah-masalah mereka sendiri di tingkat individual, keluarga, dan komunitas. Kedua, mengembangkan struktur-struktur dan proses organisasiorganisasi yang berfungsi menurut kaidah-kaidah sistem organisasi. Ketiga, Mengembangkan sistem-sistem produksikonsumsi yang diorganisasi secara teritorial yang berlandaskan pada kaidahkaidah pemilikan dan pengendalian lokal. ${ }^{33}$

Asosiasi dituntut untuk melakukan penguatan dengan mengedepankan ekonomi kerakyatan sebagai pemecahan permasalahan kesejahteraan peternaksapi perah, sebagaimana diamantkan dalam Pasal 33 Undang-Undang Dasar 1945 Perubahan Bab XIV. ${ }^{34}$ Ekonomi kerakyatan dan doktrin ekonomi Indonesia muncul dari falsafah Pancasila yang merupakan subsistem dari UUD 1945. Pasal utama bertumpunya doktrin ekonomi Indonesia adalah pasal 33 UUD 1945, dengan kelengkapannya pasal 27 ayat 2 dan pasal 34. Pasal-pasal itu bila dikaitkan dengan

32 Lazimnya perbedaan tersebut terkait dengan pengelolaan keuangan.

33 Hikmat, Harry, Strategi Pemberdayaan Masyarakat,. Humaniora, Bandung, 2004, hlm. 15-16.

34 Ekonomi kerakyatan yang adalah (sistem) ekonomi yang demokratis termuat lengkap dalam Penjelasan Pasal 33 UUD 1945 sebelum dilakukan Amandemen, al: produksi dikerjakan oleh semua untuk semua di bawah pimpinan atau pemilikan anggota masyarakat. Kemakmuran masyarakatlah yang diutamakan bukan kemakmuran orang-seorang. Sebab itu perekonomian disusun sebagai usaha bersama berdasar atas asas kekeluargaan. 
kerangka kerja ekonomi kerakyatan jelas mempunyai hubungan yang sangat erat. Sebab dalam ekonomi kerakyatan memuat pesan-pesan moral yang berasaskan kekeluargaan dan kebersamaan serta berintikan kerakyatan. ${ }^{35}$

Ekonomi kerakyatan sesungguhnya mencakup tiga hal berikut: Pertama, adanya partisipasi penuh seluruh anggota masyarakat dalam proses pembentukan produksi nasional. Partisipasi penuh seluruh masyarakat dalam proses pembentukan produksi nasional ini sangat penting Kedua, adanya partisipasi seluruh anggota masyarakat dalam turut menikmati hasil produksi nasional. Ketiga, pembentukan produksi dan pembagian hasil produksi nasional harus berada di bawah pimpinan atau penilikan anggota masyarakat. Artinya, dalam rangka ekonomi kerakyatan, anggota masyarakat tidak boleh hanya menjadi objek. Setiap anggota masyarakat harus diupayakan agar menjadi subjek perekonomian. ${ }^{36}$

\section{Peternak Sapi Perah}

Peternak sapi perah menjadi salah satu bagian dari peternak untuk dilakukan peningkatan kualitas hidup yang selaras dengan pembangunan nasional sebagai sarana strategis guna meningkatkan kesejahteraan masyarakat, dengan diarahkan untuk membentuk manusia seutuhnya yaitu untuk membangun kesejahteraan masyarakat Indonesia seluruhnya. Landasan ini menyebabkan ruang lingkup pembangunan nasional sangat luas, maka pelaksanaannya harus secara terencana, menyeluruh, bertahap dan berlanjut. Pada tiap-tiap tahap diharapkan dicapai keselarasan dalam kemajuan lahiriah dan batiniah yang merata mencakup seluruh rakyat, dengan kadar keadilan sosial yang meningkat. ${ }^{37}$

Perkembangan peternakan sapi perah di Indonesia tidak terlepas dari sejarah perkembangannya dan kebijakan pemerintah sejak zaman Hindia Belanda untuk memenuhi kebutuhan orang-orang Belanda dan diusahakan oleh nonpribumi, dan barn pada tahun 1925. Peternakan rakyat sapi perah tumbuh sejak zaman pendudukan Jepang dan Revolusi Fisik Kemerdekaan Indonesia (1942-1950), karena pada saat itu perusahaan sapi perah terbengkalai dan ditinggalkan pemiliknya. Kurun waktu antara 19501961-pada periode usaha rehabilitasimelalui Rencana Kemakmuran Istimewa (RKI), bidang peternakan mulai mendapat perhatian, meskipun belum sebagai prioritas utama. $^{38}$

Peternakan sapi perah di Indonesia saat ini sebagian besar (90\%) masih merupakan usaha peternakan rakyat yang merupakan defenisi usaha tani

\footnotetext{
35 Ayub Barombo, Asrori, Donatianus, Pemberdayaan Masyarakat Melalui Koperasi Credit Union (CU) studi pada cu. Khatulistiwa bakti pontianak, PMIS-Untan - Jurnal Tesis 2012, hlm. 6.

36 Bambang Basuki, Ekonomi Kerakyatan Berhadapan Dengan Neoliberalisme, Jurnal Analisa Vol. 1, No. 1, April 2013, 12-13.

37 Sri Hartini, Tedi Sudrajat, dan Rahadi Wasi Bintoro, Model Perlindungan Hukum Terhadap Kebijakan Pelayanan Kesehatan Masyarakat Miskin Di Kabupaten Banyumas, Jurnal Dinamika Hukum Vol. 12 No. 3 September 2012, hlm. 523.

38 Subandriyo dan Adiarto. Sejarah Perkembangan Peternakan Sapi Perah. LIPI Press, Jakarta, 2009, hlm. 1.
} 
dalam arti sempit dengan tujuan utama untuk memenuhi kebutuhan subsistensi petani dan keluarganya. Atmadilaga mengemukakan bahwa peternakan rakyat merupakan suatu usaha keluarga yang tidak menggunakan hukum ekonomi produksi secara ketat. Kesempatan ekonomi dalam memanfaatkan setiap peluang yang menguntungkan sedangkan manifestasinya berbeda-beda di berbagai daerah sesuai dengan pola pertanian dan pola tanam. Selanjutnya dikatakan bahwa pemeliharaan ternak yang dilakukan para petani di pedesaan masih bersifat tradisional. Namun demikian, usaha peternakan sapi perah sampai saat ini masih terus bertahan. Rendahnya produktivitas sapi perah disebabkan oleh kondisi manajemen usaha sapi perah di tingkat peternak yang masih tradisional. Manajemen budidaya (on farm) yang baik dan benar belum diadopsi dengan sempurna oleh peternak. Hal ini diperburuk dengan sistem mata rantai pen umpulan distribusi susu yang tidak memadai. ${ }^{39}$

Pemerintah telah mengupayakan pengembangan sapi perah dalam rangka peningkatan produksi dan produktivitas. Upaya tersebut antara lain pemberian kredit sapi perah melalui koperasi dan pemasaran susu diatur melalui industri pengolahan susu (IPS) sejak tahun 1982-1997, namun kebijakan sistem perkoperasian sapi perah oleh pemerintah belum menyejahterakan peternak karena kurang memperhatikan strategi manajemen produksi. Berdasarkan hal tersebut, maka permasalahan utama yang perlu dipecahkan adalah bagaimana koperasi sapi perah dalam jangka pendek dapat meningkatkan pendapatan peternak sapi perah. Peningkatan pendapatan peternak erat kaitannya dengan biaya produksi dan manajemen usaha. ${ }^{40}$

\section{PENUTUP}

Perlindungan terhadap hak-hak yang dimiliki oleh peternak sapi perah tidak boleh diabaikan, bila perbaikan kualitas kehidupan menjadi tujuannya. Perlindungan ini dapat dilakukan dengan mengedepankan hukum sebagai kaidah atau norma dalam menentukan kebijakankebijakan yang terkait dengan peternak sapi perah. Asosiasi atau perkumpulan yang menaungi para peternak sapi perah merupakan cara logis untuk dapat menjalankan kebijakan-kebijakan yang terkait dengan kewajiban dan hakhak yang dimiliki oleh peternak sapi perah. Asosiasi menjadi penting untuk dibicarakan dengan sebab perkumpulan ini merupakan wadah yang secara logis dapat memberikan pengaruh terhadap kebijakan itu sendiri.

Peternakan sapi perah secara individu bila dihadapkan dengan kebijakankebijakan yang tidak menguntungkan, memiliki kemampuan yang kurang dalam melakukan penolakan terhadap hal tersebut. Tugas asosiasi ini menjadi

39 Marina Sulistyati, Hermawan, dan Anita Fitriani, Potensi Usaha Peternakan Sapi Perah Rakyat dalam Menghadapi Pasar Global, Jurnal Ilmu Ternak, Juni 2013, Vol. 13, No. 1, hlm. 17.

40 Siswanto Imam Santosa, Agus Setiadi, dan Ratih Wulandari, Analisis Potensi Pengembangan Usaha Peternakan Sapi Perah Dengan Menggunakan Paradigma Agribisnis Di Kecamatan Musuk Kabupaten Boyolali, Buletin Peternakan Vol. 37(2): 125-135, Juni 2013, hlm. 126. 
penyeimbang sebagai bagian dari Negara yang memiliki tugas dan fungsi sebagai sebuah organisasi dengan mengedepankan perlindungan kepada penduduk sebagai sebuah konsekuensi dari hidup bernegara, dengan mengedepankan regulasi sebagai titik tolak tindakan yang dilakukan negara, Negara mendukung atau langsung keterlaksanaan kegiatan tersebut dalam bentuk peraturan perundang-undangan.

\section{DAFTAR PUSTAKA}

\section{Buku}

Adi Fahrudin, Pengantar Kesejahteraan Sosial, Refika Aditama, Bandung, 2012.

Baharudin Lopa, Permasalahan Pembinaan

Dan Penegakan Hukum Di Indonesia, Bulan Bintang, Jakarta, 1987.

Hikmat, Harry, Strategi Pemberdayaan Masyarakat,. Humaniora, Bandung, 2004.

Juniarso Ridwan, Achmad Sodik Sudrajat, Hukum Administrasi Negara Dan Kebijakan Pelayan Publik, Nuansa Cendekia, Bandung, 2014.

M. Syukri Akub, Baharuddin Baharu, Wawasan Due Proses of Law Dalam Sistem Peradilan Pidana, Rangkang Education, Yogyakarta, 2012.

Mukhti Fadjar, Tipe Negara Hukum, Banyumedia, Malang, 2004.
Philipus M. Hadjon, Perlindungan Hukum bagi Rakyat di Indonesia, Bina Ilmu, Surabaya, 1987.

Sudikno Mertokusumo, Bab-Bab Tentang Penemuan Hukum, Citra Adtya Bakti, Bandung, 1993.

Suharsimi Arikunto, Prosedur Penelitian Suatu Pendekatan Praktek, Rineka Cipta, Jakarta, 1997.

\section{Tesis}

Ni Gusti Ayu Hendrani Sukma Lestari, Eksistensi Klausul Pengaman Dalam Keputusan Gubernur Bali Yang Berkarakter Keputusan Tata Usaha Negara, Tesis Program Magister Program Studi Ilmu Hukum Program Pascasarjana Universitas Udayana, Denpasar, 2010.

\section{Jurnal}

Dainto Bachriadi, Refleksi Satu Dasarwa Reformasi dalam Perspektif Reforma Agraria, Jurnal Analisis Sosial Vpl. 15 No. 1 Agustus 2010.

Dani Pinasang, Falsafah Pancasila Sebagai Norma Dasar (Grundnorm) Dalam Rangka Pengembanan Sistem Hukum Nasional, Dinamika Hukum Vol.XX/ No.3/April-Juni/2012.

Deden Sumantry, Reformasi Perpajakan Sebagai Perlindungan Hukum Yang Seimbang Antara Wajib Pajak Dengan Fiskus Sebagai Pelaksanaan Terhadap 
Undang-Undang Perpajakan, Jurnal Legislasi Indonesia, Vol. 8 No. 1 - April 2011.

Erwan Agus Purwanto, Mengkaji Potensi Usaha Kecil dan Menengah (UKM) untuk Pembuatan Kebiiakan Anti Kemiskinan di Indonesia, Jurnal Ilmu Sosial dan Ilmu Politik, Volume 10, Nomor 3, Maret 2007.

Marina Sulistyati, Hermawan, dan Anita Fitriani, Potensi Usaha Peternakan Sapi Perah Rakyat dalam Menghadapi Pasar Global, Jurnal Ilmu Ternak, Juni 2013, Vol. 13, No. 1.

Rizaldy Muhammad Milad, Sa'adatul Munawaroh, dan Yuni Ningtiyas, Perkembangan Mata Pencaharian Peternakan, Artikel Ilmiah, Universitas Negeri Malang, 2014.

Rudy Hendra Pakpahan dan Eka N. A. M. Sihombing, Tanggung Jawab Negara dalam Pelaksanaan Jaminan Sosial, Jurnal Legislasi Indonesia, Vol. 9 No. 2 - Juli 2012.

Satjipto Rahardjo, Penyelenggaraan Keadilan dalam Masyarakat Yang Sedang Berubah, Jurnal Masalahmasalah Hukum, Nomor: 1-6 Tahun x/10, 1993.

Siswanto Imam Santosa, Agus Setiadi, dan Ratih Wulandari, Analisis Potensi Pengembangan Usaha Peternakan Sapi Perah Dengan Menggunakan Paradigma Agribisnis Di Kecamatan
Musuk Kabupaten Boyolali, Buletin Peternakan Vol. 37(2): 125-135, Juni 2013.

Sri Hartini, Tedi Sudrajat, dan Rahadi Wasi Bintoro, Model Perlindungan Hukum Terhadap Kebijakan Pelayanan Kesehatan Masyarakat Miskin Di Kabupaten Banyumas, Jurnal Dinamika Hukum Vol. 12 No. 3 September 2012.

Sutrisno, Politik Hukum Perlindungan dan Pengelolaan Lingkungan Hidup, Jurnal Hukum Universitas Islam Indonesia, No. 3 Vol. 18 Juli 2011.

Y. Sri Pudyatmoko, Perizinan, Problem dan Upaya Pembenahan, Gramedia Widiarsana Indonesia, Jakarta, 2009

\section{Peraturan Perundang-Undangan}

Undang-Undang No. 26 tahun 2000 tentang Pengadilan Hak Asasi Manusia.

Undang-Undang Nomor 18 Tahun 2009 Tentang Peternakan Dan Kesehatan Hewan.

$\begin{array}{lrr}\text { Lampiran } & \text { Peraturan } & \text { Menteri } \\ \text { Pertanian } & \text { Nomor } & \text { 19/Permentan/ } \\ \text { HK.140/4/2015 Tentang } & \text { Rencana } \\ \text { Strategis Kementerian } & \text { Pertanian } \\ \text { Tahun 2015-2019. } & \end{array}$

Lampiran Peraturan Presiden No. 2 Tahun 2015 Tentang Rencana Pembangunan Jangka Menengah Nasional 20152019 Buku I Agenda Pembangunan Nasional, Kementerian Perencanaan 
Pembangunan Nasional/ Badan

Perencanaan Pembangunan Nasional, 2014.

\section{Internet}

http://www.cnnindonesia.com/ekono $\mathrm{mi} / 20160422185106-92-125934$ / produksi-susu-sapi-ind onesiatersumbat-rendahnya-harga/, Diakses terakhir pada 1 Agustus 2016 pukul 11.30 Waktu Indonesia Barat (WIB). 